\title{
Batasan indeks massa tubuh dan lingkar perut diabetesi di Indonesia untuk prediksi abnormalitas kadar HDL-kolesterol dan tekanan darah
}

Body mass index and waist circumference cut-off point of Indonesian diabetics as predictor of their HDL-cholesterol level and blood pressure abnormality

Nazarina ${ }^{1}$, Sri Prihartini' ${ }^{1}$, Rika Rachmawati ${ }^{1}$

\begin{abstract}
Background: According to National Basic Health Survey (Riskesdas) 2007 and 2013 in Indonesia, diabetes prevalence had been increasing from 1,1\% to 1,5\%. Diabetic tends to have obesity related to abnormal blood lipid level and high blood pressure which lead to some complications such as cardiovascular diseases and hypertention. Therefore early prevention of complications is needed. Objective: This study was to identify body mass index (BMI) and waist circumference (WC) cut-off point in Indonesian diabetic as predictor of lipid profile and high blood pressure abnormality. Method: Crossectional study using secondary data, Riskesdas 2007. Subjects in this study were 615 diabetics who admitted been diagnosed as diabetes by physicians and/or had oral glucose test result $\geq 200 \mathrm{mg} \%$. Data that had been analyzed were lipid profile (total cholesterol, LDL-chol, HDL-chol) and systolic-diastolic blood pressure, $B M I\left(\mathrm{~kg} / \mathrm{cm}^{2}\right), W C(\mathrm{~cm})$, life style, and subject's characteristic. Receiver Operating Characteristic (ROC) is used to identify BMI and WC cut-off point for predicting lipid profile and blood pressure abnormality. Results: On the average, subjects have high blood pressure and dyslipidemia. Both IMT and LP are able to predict high blood pressure and low $H D L$-chol significantly $(A U C \geq 59$; all $p>0,05)$. BMI=23 kg/ $\mathrm{cm}^{2}$ can predict low $\mathrm{HDl}$-chol $(\mathrm{Se}=63,3 \% ; \mathrm{Sp}=54,0 \%$; $p=0,04)$, high systolic $(\mathrm{Se}=68,3 \% ; \mathrm{Sp}=60,6 \% ; p=0,000)$ and diastolic $(\mathrm{Se}=68,3 \%$; $\mathrm{Sp}=60,6 \% ; p=0,000)$ blood pressure in men, whereas in women can predict only low HDL-chol (Se=72,3\%; Sp=47,8\%; $p=0,000) . L P=80 \mathrm{~cm}$ can screen high systolic (Se=73,8\%; $S p=63,6 \% ; p=0,000)$ and diastolic $(S e=72,4 \% ; S p=55,3 \% ; p=0,000)$ blood pressure in men and high systolic blood pressure in women $(\mathrm{Se}=71,5 \% ; \mathrm{Sp}=52,6 \%$; $p=0,000)$. However, to predict low $\mathrm{HDL}$-chol in women, cut-off point of LP is $78 \mathrm{~cm}(\mathrm{Se}=74,2 \%$; $S p=41,5 \%$; $=0,003)$. Conclusion: Although BMI and LP can be used to predict high blood pressure and low HDL-chol, however both measures have different function when they are applied in both gender. To predict low HDL-chol in men and women, BMI=23 $\mathrm{kg} / \mathrm{cm}^{2}$ can be used, and LP=80 cm can be applied to screen high systolic blood pressure in both gender. Nevertheless, more research is needed to show the consistency of these results, such as using better study design and considering for confounding variables (ethnic, diabetes duration, life style, hypertension, and diabetes medicine).
\end{abstract}

KEY WORDS: diabetes, body mass index, waist circumference, HDL-cholesterol, blood pressure

\begin{abstract}
ABSTRAK
Latar belakang: Menurut Riskesdas 2007 dan 2013, prevalensi diabetes di Indonesia meningkat dari 1,1\% menjadi 1,5\%. Penyandang diabetes (diabetesi) memiliki kecenderungan menjadi obesitas yang berhubungan dengan kadar lipid darah dan tekanan darah tidak normal yang kemudian berakhir dengan komplikasi, seperti penyakit kardiovaskular dan hipertensi. Deteksi dini kemungkinan akan terjadinya komplikasi sangat diperlukan. Tujuan: Mengidentifikasi batasan (cut-off point) indeks massa tubuh (IMT) dan lingkar perut (LP) pada diabetesi di Indonesia sebagai prediksi abnormalitas kadar lipid darah dan tekanan darah. Metode: Penelitian cross-sectional menggunakan data Riskesdas 2007. Subjek penelitian adalah 615 diabetesi yang pernah didiagnosis diabetes oleh tenaga medis dan/atau memiliki hasil tes glukosa oral $\geq 200 \mathrm{mg} \%$. Data yang dianalisis adalah kadar profil lipid (kolesterol total, LDL-kol, HDL-kol); tekanan darah (sistolik, diastolik); IMT (kg/. $\left.\mathrm{cm}^{2}\right)$; LP (cm); gaya hidup; dan karakteristik subjek. Receiver Operating Characteristic (ROC) digunakan untuk mengidentifikasi cut-off point IMT dan LP dalam memprediksi abnormalitas kadar lipid darah dan tekanan darah. Hasil: Subjek memiliki rerata tekanan darah yang tinggi dan dislipidemia. Kedua pengukuran IMT dan LP dapat memprediksi tekanan darah tinggi dan kadar HDL-kol rendah secara signifikan (AUC $\geq 59 ; \mathrm{p}>0,05)$. IMT $=23 \mathrm{~kg} / \mathrm{cm}^{2}$ dapat memprediksi kadar HDl-kol rendah $(\mathrm{Se}=63,3 \% ; \mathrm{Sp}=54,0 \% ; \mathrm{p}=0,04)$, tekanan darah sistolik $(\mathrm{Se}=68,3 \%$; $\mathrm{Sp}=60,6 \% ; \mathrm{p}=0,000)$ dan diastolik $(\mathrm{Se}=68,3 \% ; \mathrm{Sp}=60,6 \% ; \mathrm{p}=0,000)$ tinggi pada laki-laki sedangkan pada perempuan hanya dapat memprediksi kadar HDL-kol rendah $(\mathrm{Se}=72,3 \% ; \mathrm{Sp}=47,8 \% ; \mathrm{p}=0,000)$. LP=80 $\mathrm{cm}$ dapat menapis tekanan darah sistolik $(\mathrm{Se}=73,8 \% ; \mathrm{Sp}=63,6 \% ; \mathrm{p}=0,000)$ dan diastolik $(\mathrm{Se}=72,4 \% ; \mathrm{Sp}=55,3 \% ; \mathrm{p}=0,000)$ tinggi pada laki-laki dan tinggi pada perempuan ( $\mathrm{Se}=71,5 \% ; \mathrm{Sp}=52,6 \% ; \mathrm{p}=0,000)$. Namun, untuk memprediksi kadar HDL-kol rendah pada perempuan,
\end{abstract}

\footnotetext{
${ }^{1}$ Korespondensi: Pusat Teknologi Terapan Kesehatan dan Epidemiologi Klinik, Badan Penelitian dan Pengembangan Kesehatan, Kementerian Kesehatan-BogorIndonesia, Jl. DR. Semeru No.63, Bogor 16112,e-mail: nazarina@litbangdepkes.go.id
} 
batasan $\mathrm{LP}=78 \mathrm{~cm}(\mathrm{Se}=74,2 \% ; \mathrm{Sp}=41,5 \% ; \mathrm{p}=0,003)$. Simpulan: Meskipun IMT dan LP dapat untuk memprediksi tekanan darah tinggi dan LDL-kol rendah, tetapi kedua ukuran tersebut memiliki fungsi berbeda pada saat akan digunakan untuk kedua jenis

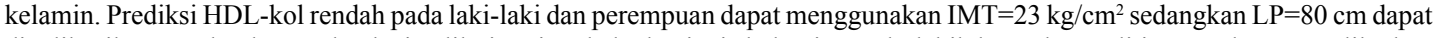
diaplikasikan untuk tekanan darah sistolik tinggi pada kedua jenis kelamin. Perlu lebih banyak penelitian untuk memperlihatkan hasil yang konsisten, seperti penggunaan disain penelitian yang lebih baik dan mempertimbangkan variabel pengganggu (etnik, durasi diabetes, gaya hidup, penggunaan obat diabetes dan hipertensi).

KATA KUNCI: diabetes, indeks massa tubuh, lingkar perut, HDL-kolesterol, tekanan darah

\section{PENDAHULUAN}

Diabetes mellitus (DM) merupakan salah satu sindroma metabolik yang bersifat kronis yang disebabkan oleh penurunan fungsi pankreas dan atau adanya resistensi insulin sehingga menyebabkan hiperglikemik (1). Berdasarkan data Riskesdas 2007 dan 2013, prevalensi DM di Indonesia meningkat dari 1,1\% menjadi 1,5\% (2). Penyandang diabetes (diabetesi) pada umumnya akan mengalami kegemukan sebagai manifestasi perubahan metabolik hormon insulin dan leptin yang berdampak pada hiperfagia (3). Diabetes dan kegemukan akan menyebabkan terjadinya komplikasi. Keadaan tersebut banyak terjadi di negara berkembang. Kegemukan atau pun obesitas juga berperan terhadap peningkatan kejadian hipertensi global (4).

Penelitian di Minnesota, Amerika Serikat menemukan bahwa prevalensi obesitas pada individu yang pertama kali didiagnosis diabetes, meningkat dari waktu ke waktu. Diketahui bahwa diabetesi yang sangat obesitas, meningkatkan risiko mortalitas (5). Tingginya mortalitas dan morbiditas pada penyandang diabetes tersebut, merupakan manifestasi dari komplikasi makro dan mikrovaskuler. Komplikasi makrovaskuler antara lain berupa infark miokard, stroke, dan kardiovaskuler (6). Salah satu faktor risiko stroke adalah tingginya tekanan darah sedangkan faktor risiko penyakit kardiovaskuler adalah kelainan kadar lipid darah, serta ukuran total adiposa tubuh yang tinggi. Adiposa dapat diukur dengan indeks massa tubuh (IMT) sehingga IMT dapat digunakan untuk memprediksi risiko penyakit jantung. Namun demikian, jika dibandingkan IMT, obesitas sentral yang diukur dengan lingkar perut (LP), merupakan prediktor yang lebih kuat untuk memprediksi penyakit jantung (7). Lingkar perut merupakan bagian dari pengukuran lemak viseral. Asam lemak pada lemak viseral bersifat mobile sehingga mudah lepas dan masuk ke dalam vena portal yang langsung menuju ke hati. Hal tersebut yang kemungkinan menjadi penyebab meningkatnya kejadian dislipidemia yang ditandai dengan kelainan profil lipid darah (8).

Kegemukan berkaitan dengan gaya hidup seperti tingginya asupan makanan manis dan makanan berlemak, serta aktivitas fisik yang rendah. Keadaan tersebut kemudian akan berdampak terhadap kadar glukosa darah yang tinggi, kelainan profil lipid, dan tekanan darah tinggi. Merokok berkaitan dengan kegemukan karena nikotin pada rokok dapat menyebabkan disregulasi pelepasan hormon leptin sehingga hormon leptin meningkat dan nafsu makan berkurang (9). Indeks massa tubuh merupakan ukuran yang sering digunakan untuk menyatakan kegemukan. Pada umumnya, nilai batasan (cut-off point) IMT ditentukan berdasarkan pada persentase (\%) lemak tubuh yang dibedakan menurut usia, jenis kelamin, dan kelompok etnik. Contohnya, orang Indonesia memiliki batasan IMT kegemukan yang lebih rendah daripada orang Belanda (10). Hal ini karena persentase lemak tubuh orang Indonesia 4,8\% lebih banyak dibandingkan orang Belanda pada usia dan jenis kelamin yang sama (11).

Pada konsultasi gizi atau diit diabetes, penentuan status gizi menjadi sangat penting karena dapat dijadikan salah satu faktor yang dipertimbangkan dalam penentuan jumlah kalori pada diit diabetes. Salah satu tujuan diit diabetes antara lain agar diabetesi terhindar dari penyakit penyerta dan komplikasi (12). Selain status gizi dapat digunakan dalam penentuan diit diabetes, dimungkinkan pula informasi status gizi (IMT) dan status obesitas sentral (LP) dapat digunakan sebagai alat penapisan yang mudah dan murah untuk masalah profil lipid dan tekanan darah pada diabetesi. Penapisan tersebut diharapkan akan dapat mencegah penyakit penyerta ataupun komplikasi pada diabetesi. Selama ini belum ada batasan IMT atau pun LP bagi diabetesi, padahal diperlukan karena diabetesi berisiko lebih tinggi mengalami kegemukan, obesitas, 
dislipidemia, dan hipertensi dibandingkan yang bukan diabetes. Oleh karena itu, penelitian ini dilakukan untuk mendapatkan nilai batasan IMT dan LP pada diabetesi yang dapat digunakan sebagai alat skrining kelainan profil lipid dan tekanan darah. Selain itu, batasan IMT dan LP diabetesi yang dihasilkan tersebut diharapkan juga akan dapat dipertimbangkan untuk menentukan jumlah kalori diit diabetes.

\section{BAHAN DAN METODE}

Desain penelitian ini adalah cross sectional dengan menggunakan data riset kesehatan dasar (Riskesdas) tahun 2007 yang telah mendapat persetujuan etik dari Komite Etik Badan Penelitian dan Pengembangan Kesehatan, Kementerian Kesehatan Republik Indonesia. Subjek penelitian ini adalah diabetesi yang ditetapkan berdasarkan pengakuan subjek yang pernah didiagnosis diabetes oleh tenaga medis atau dokter dan atau berdasarkan hasil tes toleransi glukosa oral (TTGO) pada saat survei dilakukan. Selanjutnya, subjek harus memenuhi kriteria inklusi dan ekslusi.

Kriteria inklusi subjek adalah usia subjek lebih dari atau sama dengan 20 tahun, memiliki data lengkap glukosa darah 2 jam setelah pembebanan 75 g glukosa, kolesterol total, low-density lipoprotein-kolesterol (LDL-kol), high-density lipoprotein-kolesterol (HDLkol), tekanan darah sistolik dan diastolik, berat badan, tinggi badan, serta LP. Selain itu, subjek memiliki data lengkap tentang usia, jenis kelamin, aktivitas fisik, status merokok, serta pola konsumsi buah-sayur, makanan asin, manis, dan berlemak. Subjek yang datanya masuk ke dalam analisis penelitian ini adalah subjek yang telah bersedia berpartisipasi dalam penelitian Riskesdas 2007 dengan menandatangani lembar persetujuan (consent form). Individu dengan kondisi hamil dan atau menyusui dieksklusi dari penelitian. Dengan demikian, jumlah subjek yang diikutkan pada penelitian ini sebanyak 615 diabetesi di Indonesia, yaitu $82,4 \%$ subjek berada di wilayah Indonesia bagian barat; $16,1 \%$ di wilayah Indonesia bagian tengah; sisanya hanya $1,5 \%$ berada di Indonesia bagian timur.

Hampir semua data yang diperoleh yaitu usia, status merokok, aktivitas fisik, serta data pola konsumsi makanan, profil lipid (kadar kolesterol, LDL-kol, dan HDL-kol), dan tekanan darah dibuat dalam skala kategori, kecuali data IMT $\left(\mathrm{kg} / \mathrm{m}^{2}\right)$ dan LP $(\mathrm{cm})$ menggunakan skala numerik. Penentuan status gizi dilakukan berdasarkan IMT yaitu berat badan dibagi dengan kuadrat tinggi badan $\left(\mathrm{kg} / \mathrm{m}^{2}\right)$ sedangkan obesitas sentral berdasarkan pengukuran LP $(\mathrm{cm})$

Penelitian ini mengkategorikan data profil lipid dan tekanan darah menjadi normal dan tinggi sedangkan HDL-kol dikategorikan menjadi rendah dan normal. Kategori tinggi bila kadar kolesterol total $\geq 200 \mathrm{mg} /$ dl; LDL-kol $\geq 100 \mathrm{mg} / \mathrm{dl}$; tekanan darah sistolik $\geq 130$ $\mathrm{mmHg}$; dan diastolik $\geq 80 \mathrm{mmHg}$. HDL-kol dikategorikan rendah bila kadarnya $\leq 40 \mathrm{mg} / \mathrm{dl}$ untuk laki-laki dan $\leq 50$ $\mathrm{mg} / \mathrm{dl}$ untuk perempuan (13). Data tekanan darah yang digunakan pada penelitian ini merupakan hasil rerata dua kali pengukuran tekanan darah. Namun, jika dua kali hasil pengukuran tersebut memiliki selisih $\geq 10 \mathrm{mmHg}$, maka data tekanan darah yang digunakan adalah rerata dari hasil tiga kali pengukuran.

Aktivitas fisik diterjemahkan ke dalam aktivitas sedentari berdasarkan aktivitas ringan yang dilakukan per hari. Aktivitas sedentari yaitu nonton, duduk, kerja di depan komputer, membaca, dll, tetapi tidak termasuk tidur. Aktivitas fisik juga dikategorikan menjadi aktif dan kurang aktif berdasarkan aktivitas berat (menimba air, mendaki gunung, lari cepat, menebang pohon, mencangkul, dll) dan atau sedang (menyapu, mengepel, dll). Kategori aktif jika subjek melakukan aktivitas berat dan atau sedang, sementara kategori kurang aktif jika subjek tidak melakukan aktifitas berat atau sedang (2).

Data konsumsi makanan pada penelitian ini meliputi pola konsumsi buah-sayur dan kebiasaan konsumsi makanan berisiko. Pola konsumsi buah-sayur merupakan kebiasaan konsumsi buah-sayur sehari yang dinyatakan ke dalam ukuran porsi. Satu porsi buah-sayur adalah 100 g. Kebiasaan konsumsi makanan berisiko merupakan frekuensi konsumsi dari setiap makanan yang berisiko terhadap kesehatan. Pada studi ini, makanan berisiko meliputi makanan manis, berlemak, jeroan, dibakar, asin, awetan, penyedap, dan berkafein. Kebiasaan konsumsi makanan berisiko dikategorikan jarang jika makanan dikonsumsi 3 bulan sekali atau tidak pernah; kadang-kadang bila dikonsumsi 1-2 kali 
seminggu; sering bila dikonsumsi 3-6 kali seminggu; dan setiap hari bila dikonsumsi setiap hari.

Sebelum dianalisis, data diolah melalui proses editing dan cleaning. Cleaning dilakukan pada missing dan outlier values ataupun nilai ekstrim pada setiap variabel serta konsistensi antarvariabel. Setiap proses manajemen data dicatat kejadiannya. Analisis data dilakukan dengan uji Chi-Square dan kurva Receiver Operating Characteristic (ROC). Pada analisis ROC, diperoleh nilai sensitivitas dan spesifisitas, tetapi karena nilai cut-off point IMT dan LP yang dihasilkan dari analisis ROC adalah dalam bentuk angka pecahan sehingga akan mengalami kesulitan untuk diterapkan, maka dilakukan pembulatan nilai IMT dan LP dan dihitung nilai sensitivitas (Se) dan spesifisitas (Sp) dengan rumus $\mathrm{Se}=($ true negative/(true negative + false positive) $)$ x $100 \%$ dan $\mathrm{Sp}=$ (true positive/(true positive + false negative)) x 100\% (14).

\section{HASIL}

Dari 615 subjek diabetes, sebagian besar $(71,1 \%)$ merupakan undiagnosed diabetes (UDDM) karena mengaku belum pernah didiagnosis diabetes oleh tenaga medis, tetapi pada saat survei menunjukkan bahwa hasil TTGO berdasarkan kadar glukosa 2 jam post prandial (pp) lebih dari atau sama dengan $200 \mathrm{mg} \%$. Beberapa subjek mengaku pernah didiagnosis hipertensi $17,7 \%$ (109/615), penyakit jantung 3,4\% (21/615), dan stroke 1,5\% (9/615) oleh tenaga medis. Sebagian besar subjek adalah perempuan $(61,3 \%)$ dan hampir separuh jumlah subjek berada pada kelompok usia 46-59 tahun (45,9\%) sedangkan proporsi terkecil ditemukan pada kelompok usia 20-35 tahun (11,4\%). Latar belakang pendidikan subjek kebanyakan adalah tamat SD-SLTP $(40,7 \%)$ dan tidak bekerja atau sedang sekolah $(39,8 \%)$. Namun demikian, jenis pekerjaan terbesar kedua adalah wiraswasta termasuk pedagang dan jasa $(32,0 \%)$ (Tabel 1).

Apabila dilihat dari gaya hidup subjek (Tabel 2), maka kebanyakan gaya hidup yang dimiliki oleh diabetesi adalah tidak sehat, yaitu hanya $2,9 \%$ subjek yang mengonsumsi buah-sayur lebih dari atau sama dengan 4 porsi sehari sedangkan sebagian besar $(79,3 \%)$ konsumsinya kurang dari atau sama dengan 2 porsi/hari.
Tabel 1. Karakteristik subjek diabetes

\begin{tabular}{lc}
\hline \multicolumn{1}{c}{ Karakteristik } & n (\%) \\
\hline Jenis kelamin & \\
Laki-laki & $238(38,7)$ \\
Perempuan & $377(61,3)$ \\
Usia (tahun) & \\
\hline $20-35$ & $70(11,4)$ \\
$36-45$ & $160(26,0)$ \\
$46-59$ & $282(45,9)$ \\
$\geq 60$ & $103(16,7)$ \\
Pendidikan & \\
Perguruan tinggi & $58(9,4)$ \\
SLTA & $168(27,3)$ \\
SD/SLTP & $250(40,7)$ \\
\hline Tidak tamat SD/tidak sekolah & $139(22,6)$ \\
Pekerjaan & \\
\hline TNI/POLRI/PNS/BUMN & $77(12,5)$ \\
\hline Wiraswasta/pedagang/jasa & $197(32,0)$ \\
\hline Petani/nelayan/buruh & $71(11,6)$ \\
\hline Tidak bekerja/sekolah/IRT & $245(39,8)$ \\
\hline Lainnya & $25(4,1)$ \\
\hline
\end{tabular}

Selanjutnya, makanan berisiko yang banyak dikonsumsi setiap hari oleh subjek adalah makanan manis $(57,4 \%)$ dan makanan berbumbu penyedap $(80,4 \%)$. Namun, subjek masih memiliki beberapa gaya hidup cukup baik, yaitu bahwa hanya sebagian kecil subjek merokok setiap hari $(17,2 \%)$, tidak aktif beraktivitas fisik $(13,8 \%)$, dan memiliki aktifitas sedentari lebih dari atau sama dengan 3 jam perhari $(2,1 \%)$.

Pada Tabel 3, terlihat bahwa lebih dari separuh jumlah subjek diabetes berstatus gizi gemuk atau obesitas $(63,7 \%)$. Meskipun subjek perempuan terlihat lebih banyak mengalami kegemukan/obesitas $(66,3 \%)$ dibandingkan laki-laki (59,7\%), tetapi perbedaan tersebut tidak signifikan $(\mathrm{p}=0,095)$. Perbedaan yang signifikan $(\mathrm{p}=0,000)$ terlihat pada proporsi perempuan dengan obesitas sentral yang lebih besar $(63,9 \%)$ dibandingkan laki-laki (29,4\%).

Gambaran umum yang diperoleh dari Tabel 4 memperlihatkan bahwa subjek memiliki rerata tekanan darah sistolik dan diastolik di atas normal $(\geq 130 / 80$ $\mathrm{mmHg}$ ) dan HDL-kol di bawah kadar normal ( $\leq 50 \mathrm{mg} / \mathrm{dl})$. Meskipun demikian, subjek diabetes tidak-gemuk/tidakobesitas memiliki tekanan darah sistolik $(141,0 \pm 24,3$ vs $148,2 \pm 24,9 \mathrm{mmHg} ; \mathrm{p}=0,001)$ dan diastolik $(84,1 \pm 11,9$ vs $90,2 \pm 13,3 \mathrm{mmHg} ; \mathrm{p}<0,000$ ) yang lebih rendah, serta 
Tabel 2. Gaya hidup subjek diabetes

\begin{tabular}{|c|c|c|}
\hline Gaya hidup & $\mathbf{n}$ & $\%$ \\
\hline \multicolumn{3}{|l|}{ Kebiasaan merokok } \\
\hline Tidak merokok/merokok tidak setiap hari & 509 & 82,8 \\
\hline Merokok setiap hari & 106 & 17,2 \\
\hline \multicolumn{3}{|l|}{ Aktifitas sedang-berat } \\
\hline Aktif & 530 & 86,2 \\
\hline Tidak aktif & 85 & 13,8 \\
\hline \multicolumn{3}{|l|}{ Aktifitas sedentari } \\
\hline$<3$ jam/hari & 602 & 97,9 \\
\hline$\geq 3 \mathrm{jam} / \mathrm{hari}$ & 13 & 2,1 \\
\hline \multicolumn{3}{|l|}{ Konsumsi buah-sayur } \\
\hline$>4$ porsi/hari & 18 & 2,9 \\
\hline 3,1-4 porsi/hari & 38 & 6,1 \\
\hline 2,1-3 porsi/hari & 71 & 11,5 \\
\hline 1,1-2 porsi/hari & 347 & 56,4 \\
\hline$\leq 1$ porsi/hari & 141 & 22,9 \\
\hline \multicolumn{3}{|l|}{ Makanan manis } \\
\hline Jarang & 123 & 20,0 \\
\hline Kadang & 74 & 12,0 \\
\hline Sering & 65 & 10,6 \\
\hline Setiap hari & 353 & 57,4 \\
\hline \multicolumn{3}{|l|}{ Makanan berlemak } \\
\hline Jarang & 240 & 39,0 \\
\hline Kadang & 185 & 30,1 \\
\hline Sering & 88 & 14,3 \\
\hline Setiap hari & 102 & 16,6 \\
\hline \multicolumn{3}{|l|}{ Makanan jeroan } \\
\hline Jarang & 495 & 80,5 \\
\hline Kadang & 82 & 13,3 \\
\hline Sering & 27 & 4,4 \\
\hline Setiap hari & 11 & 1,8 \\
\hline \multicolumn{3}{|l|}{ Makanan dibakar } \\
\hline Jarang & 385 & 62,6 \\
\hline Kadang & 158 & 25,7 \\
\hline Sering & 58 & 9,4 \\
\hline Setiap hari & 14 & 2,3 \\
\hline \multicolumn{3}{|l|}{ Makanan asin } \\
\hline Jarang & 187 & 30,4 \\
\hline Kadang & 189 & 30,7 \\
\hline Sering & 88 & 14,3 \\
\hline Setiap hari & 151 & 24,6 \\
\hline \multicolumn{3}{|l|}{ Makanan awetan } \\
\hline Jarang & 388 & 63,1 \\
\hline Kadang & 132 & 21,5 \\
\hline Sering & 53 & 8,6 \\
\hline Setiap hari & 42 & 6,8 \\
\hline \multicolumn{3}{|l|}{ Bumbu penyedap } \\
\hline Jarang & 57 & 9,3 \\
\hline Kadang & 30 & 4,9 \\
\hline Sering & 33 & 5,4 \\
\hline Setiap hari & 495 & 80,4 \\
\hline \multicolumn{3}{|l|}{ Minuman berkafein } \\
\hline Jarang & 360 & 58,5 \\
\hline Kadang & 50 & 8,1 \\
\hline Sering & 37 & 6,0 \\
\hline Setiap hari & 168 & 27,4 \\
\hline
\end{tabular}

Tabel 3. Status gizi dan obesitas sentral pada subjek diabetes

\begin{tabular}{lccc}
\hline & $\begin{array}{c}\text { Laki-laki } \\
\text { n (\%) }\end{array}$ & $\begin{array}{c}\text { Perempuan } \\
\text { n (\%) }\end{array}$ & p \\
\hline $\begin{array}{l}\text { Status gizi } \\
\begin{array}{l}\text { Tidak gemuk/tidak } \\
\text { obes }\end{array}\end{array}$ & $96(40,3)$ & $127(33,7)$ & 0,095 \\
$\begin{array}{l}\text { Gemuk/obes } \\
\text { Obesitas sentral }\end{array}$ & $142(59,7)$ & $250(66,3)$ & \\
$\quad \begin{array}{lll}\text { Tidak obesitas sentral } \\
\text { Obesitas sentral }\end{array}$ & $168(70,6)$ & $136(36,1)$ & $0,000^{*}$ \\
\hline
\end{tabular}

Keterangan: gemuk/obes $=\mathrm{IMT}>23 \mathrm{~kg} / \mathrm{cm}^{2}$; obesitas sentral=perempuan $>80 \mathrm{~cm}$; laki-laki $>90 \mathrm{~cm}$

kadar HDL-kol yang lebih tinggi $(45,9 \pm 15,7$ vs 41,8 $\pm 15,7 \mathrm{mg} / \mathrm{dl} ; \mathrm{p}=0,002)$ dibandingkan subjek diabetes gemuk/obesitas tetapi perbedaan tersebut kecil.

Demikian pula bila dibedakan berdasarkan jenis kelamin dan status obesitas sentral (Tabel 4), maka subjek perempuan memiliki rerata tekanan darah sistolik dan diastolik tinggi $(\geq 130 / 80 \mathrm{mmHg})$ dan kadar HDLkol rendah $(\leq 50 \mathrm{mg} / \mathrm{dl})$. Namun, subjek perempuan yang tidak obesitas sentral memiliki tekanan darah sistolik $(140,1 \pm 24,6$ vs $150,8 \pm 26,3 \mathrm{mmHg} ; \mathrm{p}=0,000)$ dan diastolik $(86,1 \pm 12,1$ vs $90,3 \pm 13,4 \mathrm{mmHg} ; \mathrm{p}=0,003)$ lebih rendah dibandingkan yang obesitas sentral. Hal serupa juga untuk kadar HDL-kol, yaitu kadar HDL-kol lebih tinggi pada subjek diabetes perempuan yang tidak obesitas sentral dibandingkan yang obesitas sentral $(46,6 \pm 16,3$ vs $43,2 \pm 13,5 \mathrm{mg} / \mathrm{dl} ; \mathrm{p}=0,002)$.

Seperti subjek diabetes perempuan, subjek laki-laki yang tidak obesitas sentral memiliki tekanan darah sistolik $(139,6 \pm 21,7$ vs $152,8 \pm 22,9 \mathrm{mmHg} ; \mathrm{p}=0,000)$ dan diastolik $(84,5 \pm 22,2$ vs $92,9 \pm 13,4 \mathrm{mmHg} ; \mathrm{p}=0,000)$ lebih rendah dibandingkan yang obesitas sentral (Tabel 4). Meskipun demikian, tekanan darah di dua kelompok status obesitas sentral tersebut masih di atas normal ( $\geq 130 / 80 \mathrm{mmHg}$ ). Hasil yang menarik pada subjek laki-laki adalah kadar HDL-kol yang tinggi $(\geq 40 \mathrm{mg} / \mathrm{dl}$ ) pada yang tidak obesitas sentral dibandingkan yang obesitas sentral, tetapi perbedaan tersebut tidak signifikan $(\mathrm{p}>0,05)$.

Hasil lain yang dapat disimpulkan dari Tabel 4 yaitu subjek diabetes memiliki rerata kadar glukosa darah $2 \mathrm{jam}$ pp di atas normal ( $\geq 200 \mathrm{mg} / \mathrm{dl}$ ), total kolesterol tinggi $(\geq 200 \mathrm{mg} / \mathrm{dl})$, dan LDL-kol tinggi $(\geq 100 \mathrm{mg} / \mathrm{dl})$, tetapi keadaan tersebut tidak berbeda signifikan antarkelompok 
Tabel 4. Kadar profil lipid, glukosa, dan tekanan darah berdasarkan status gizi dan obesitas sentral

\begin{tabular}{lccc}
\hline \multicolumn{1}{c}{ Parameter } & $\begin{array}{c}\text { Tidak gemuk/ } \\
\text { Tidak obesitas }\end{array}$ & Gemuk/obesitas & p \\
\cline { 2 - 3 } & Mean \pm SD & Mean \pm SD & \\
\hline Tekanan darah sistolik (mmHg) & $141,0 \pm 24,3$ & $148,2 \pm 24,9$ & $0,001^{*}$ \\
Tekanan darah diastolik (mmHg) & $84,1 \pm 11,9$ & $90,2 \pm 13,3$ & $0,000^{* *}$ \\
Glukosa 2 jam pp (mg/dl) & $284,2 \pm 116,6$ & $273,8 \pm 98,6$ & 0,259 \\
\hline Kolesterol (mg/dl) & $217,8 \pm 58,6$ & $215,5 \pm 54,6$ & 0,654 \\
LDL-kol (mg/dl) & $136,4 \pm 46,8$ & $134,5 \pm 43,2$ & 0,617 \\
HDL-kol (mg/dl) & $45,9 \pm 15,7$ & $41,8 \pm 15,7$ & $0,002^{*}$ \\
\hline Perempuan & & & \\
\hline Tekanan darah sistolik (mmHg) & $140,1 \pm 24,6$ & $150,8 \pm 26,3$ & $0,000^{* *}$ \\
\hline Tekanan darah diastolik (mmHg) & $86,1 \pm 12,1$ & $90,3 \pm 13,4$ & $0,003 *$ \\
\hline Glukosa 2 jam pp (mg/dl) & $277,2 \pm 107,1$ & $283,9 \pm 106,0$ & 0,556 \\
\hline Kolesterol (mg/dl) & $233,7 \pm 60,3$ & $214,9 \pm 51,4$ & 0,136 \\
\hline LDL-kol (mg/dl) & $139,5 \pm 42,0$ & $134,5 \pm 42,2$ & 0,274 \\
\hline HDL-kol (mg/dl) & $46,6 \pm 16,3$ & $43,2 \pm 13,5$ & $0,031 *$ \\
\hline Laki-laki & & & \\
\hline Tekanan darah sistolik (mmHg) & $139,6 \pm 21,7$ & $152,8 \pm 22,9$ & $0,000^{*}$ \\
\hline Tekanan darah diastolik (mmHg) & $84,5 \pm 12,2$ & $92,9 \pm 13,4$ & $0,000^{*}$ \\
\hline Glukosa 2 jam pp (mg/dl) & $273,6 \pm 106,7$ & $265,8 \pm 98,5$ & 0,602 \\
\hline Kolesterol (mg/dl) & $211,7 \pm 57,5$ & $218,5 \pm 58,8$ & 0,411 \\
\hline LDL-kol (mg/dl) & $133,7 \pm 48,0$ & $132,9 \pm 49,1$ & 0,911 \\
\hline HDL-kol (mg/dl) & $42,5 \pm 19,1$ & $39,3 \pm 12,4$ & 0,189 \\
\hline
\end{tabular}

Keterangan: $* *$ signifikan $\mathrm{p}<0,01 ; *$ signifikan $\mathrm{p}<0,05$

Tabel 5. Luas area di bawah kurva (AUC) IMT dan LP terhadap kadar profil lipid dan tekanan darah berdasarkan jenis kelamin subjek

\begin{tabular}{lccccc}
\hline \multirow{2}{*}{$\begin{array}{c}\text { Profil lipid dan TD } \\
\text { (AUC; nilai p) }\end{array}$} & $\begin{array}{c}\text { Perempuan } \\
\text { \& laki-laki }\end{array}$ & Perempuan & Laki-laki & Perempuan & Laki-laki \\
\cline { 2 - 6 } & 0,$49 ; 0,960$ & 0,$49 ; 0,761$ & 0,$51 ; 0,810$ & 0,$49 ; 0,82$ & 0,$51 ; 0,81$ \\
\hline Kolesterol & 0,$46 ; 0,192$ & 0,$48 ; 0,554$ & 0,$43 ; 0,146$ & 0,$48 ; 0,53$ & 0,$43 ; 0,15$ \\
\hline LDL-kol & 0,$61 ; 0,000^{* *}$ & 0,$59 ; 0,000^{* *}$ & 0,$61 ; 0,044^{*}$ & 0,$59 ; 0,04 * *$ & 0,$57 ; 0,12$ \\
HDL-kol & 0,$62 ; 0,000^{* *}$ & 0,$56 ; 0,093$ & 0,$71 ; 0,000^{* *}$ & 0,$61 ; 0,00^{* *}$ & 0,$71 ; 0,00^{* *}$ \\
TD sistolik & 0,$63 ; 0,000^{* *}$ & 0,$54 ; 0,237$ & 0,$75 ; 0,000^{* *}$ & 0,$56 ; 0,09$ & 0,$68 ; 0,00^{* *}$ \\
\hline TD diastolik & & &
\end{tabular}

Keterangan: $* * \mathrm{p}<0,01 ; * \mathrm{p}<0,05$; IMT $=$ indeks massa tubuh; $\mathrm{LP}=$ lingkar perut; LDL-kol= low density lipoprotein-kolesterol; HDL-kol=high density lipoprotein-kolesterol; $\mathrm{AUC}=$ area under curve; TD = tekanan darah

status gizi maupun obesitas sentral ( $\mathrm{p}>0,005)$. Sejalan dengan hasil pada Tabel 4 tersebut, maka hasil analisis kurva ROC (Tabel 5) menunjukan bahwa ukuran IMT dan LP tidak dapat digunakan untuk memprediksi kadar glukosa darah, kolesterol total, dan LDL-kolesterol, baik pada subjek laki-laki maupun perempuan.

Namun, pada Tabel 5 terlihat bahwa ukuran IMT dapat membedakan kadar HDL-kol rendah pada subjek diabetes perempuan $(\mathrm{AUC}=0,59 ; \mathrm{p}=0,000)$ dan laki-laki (AUC $=0,61 ; p=0,044)$. Sementara itu, untuk prediksi tekanan darah sistolik dan diastolik tinggi, ukuran IMT secara umum dapat digunakan pada semua subjek diabetes (AUC $=0,62 ; \mathrm{p}=0,000$ dan $\mathrm{AUC}=0,63 ; \mathrm{p}=0,000$ ) tetapi apabila subjek diabetes dibedakan berdasarkan jenis kelamin, maka penggunaan IMT sebagai prediksi tekanan darah sistolik dan diastolik tinggi hanya dapat dilakukan pada subjek laki-laki (AUC $=0,71 ; p=0,000$ dan $\mathrm{AUC}=0,75$; $\mathrm{p}=0,000)$ dengan nilai AUC yang cukup tinggi.

Tekanan darah sistolik tinggi pada subjek diabetes laki-laki $(\mathrm{AUC}=0,71 ; \mathrm{p}=0,00)$ dan perempuan $(\mathrm{AUC}=0,61$; 
Tabel 6. Sensitivitas dan spesifisitas IMT terhadap kadar profil lipid dan tekanan darah berdasarkan jenis kelamin subjek

\begin{tabular}{|c|c|c|c|c|c|c|c|c|c|}
\hline IMT $\left(\mathrm{kg} / \mathrm{m}^{2}\right)$ & $\frac{A}{\text { (n) }}$ & $\begin{array}{l}\text { B } \\
\text { (n) }\end{array}$ & $\begin{array}{l}\text { C } \\
\text { (n) }\end{array}$ & $\begin{array}{l}\text { D } \\
\text { (n) }\end{array}$ & $\begin{array}{c}\text { Se } \\
(\%)\end{array}$ & $\begin{array}{l}\text { Sp } \\
(\%)\end{array}$ & $\frac{\text { PV (+) }}{(\%)}$ & $\frac{(\mathrm{PV}-)}{(\%)}$ & $\mathbf{p}$ \\
\hline \multicolumn{10}{|l|}{ HDL-kolesterol } \\
\hline \multicolumn{10}{|c|}{ Laki-laki dan perempuan } \\
\hline IMT 21 & 381 & 71 & 117 & 46 & 84,3 & 28,2 & 38,3 & 76,5 & $0,000^{* *}$ \\
\hline IMT 22 & 341 & 98 & 111 & 65 & 75,4 & 39,9 & 36,9 & 77,7 & 0,000 ** \\
\hline IMT 23 & 310 & 82 & 142 & 81 & 68,6 & 49,7 & 36,3 & 79,1 & $0,000^{* *}$ \\
\hline IMT 24 & 265 & 73 & 187 & 90 & 58,6 & 55,2 & 32,5 & 78,4 & $0,003 * *$ \\
\hline IMT 25 & 214 & 59 & 238 & 104 & 47,3 & 63,8 & 30,4 & 78,4 & $0,010^{*}$ \\
\hline \multicolumn{10}{|l|}{ Laki-laki } \\
\hline IMT 21 & 152 & 35 & 36 & 15 & 80,9 & 30,0 & 29,4 & 81,3 & 0,097 \\
\hline IMT 22 & 134 & 30 & 54 & 20 & 71,3 & 40,0 & 27,0 & 81,7 & 0,174 \\
\hline IMT 23 & 119 & 23 & 69 & 27 & 63,3 & 54,0 & 28,1 & 83,8 & $0,040^{*}$ \\
\hline IMT 24 & 97 & 19 & 91 & 31 & 51,6 & 62,0 & 25,4 & 83,6 & 0,121 \\
\hline \multicolumn{10}{|l|}{ Perempuan } \\
\hline IMT 22 & 207 & 68 & 57 & 45 & 78,4 & 39,8 & 44,1 & 75,3 & $0,006^{*}$ \\
\hline IMT 23 & 191 & 59 & 73 & 54 & 72,3 & 47,8 & 42,5 & 76,4 & $0,000^{* *}$ \\
\hline IMT 24 & 168 & 54 & 96 & 59 & 63,6 & 52,2 & 38,1 & 75,7 & $0,004 *$ \\
\hline IMT 25 & 138 & 45 & 126 & 68 & 52,3 & 60,2 & 35,1 & 75,4 & $0,027 *$ \\
\hline \multicolumn{10}{|c|}{ Tekanan darah sistolik } \\
\hline \multicolumn{10}{|c|}{ Laki-laki dan perempuan } \\
\hline IMT 21 & 355 & 126 & 58 & 56 & 85,9 & 30,8 & 49 & 74 & $0,000 * *$ \\
\hline IMT 22 & 316 & 110 & 97 & 72 & 76,5 & 39,5 & 42,6 & 74,1 & $0,000^{* *}$ \\
\hline IMT 23 & 285 & 96 & 128 & 86 & 69,0 & 47,2 & 40,2 & 74,8 & $0,000 * *$ \\
\hline IMT 24 & 249 & 79 & 164 & 103 & 60,3 & 56,6 & 38,6 & 75,9 & $0,000^{* *}$ \\
\hline IMT 25 & 202 & 61 & 211 & 66,5 & 48,9 & 66,5 & 36,4 & 76,8 & $0,000 * *$ \\
\hline \multicolumn{10}{|l|}{ Laki-laki } \\
\hline IMT 21 & 144 & 36 & 20 & 30 & 87,8 & 45,5 & 60,0 & 80,0 & $0,000^{* *}$ \\
\hline IMT 22 & 129 & 31 & 35 & 35 & 78,7 & 53,0 & 50,0 & 80,6 & $0,000^{* *}$ \\
\hline IMT 23 & 112 & 26 & 52 & 40 & 68,3 & 60,6 & 43,5 & 81,2 & $0,000 * *$ \\
\hline IMT 24 & 93 & 19 & 71 & 47 & 56,7 & 71,2 & 39,8 & 83,0 & $0,000^{* *}$ \\
\hline IMT 25 & 73 & 13 & 1 & 53 & 98,6 & 80,3 & 98,1 & 84,9 & $0,000 * *$ \\
\hline \multicolumn{10}{|c|}{ Tekanan darah diastolik } \\
\hline \multicolumn{10}{|c|}{ Laki-laki dan perempuan } \\
\hline IMT 21 & 354 & 118 & 54 & 51 & 86,8 & 30,2 & 48,6 & 75,0 & $0,000^{* *}$ \\
\hline IMT 22 & 328 & 97 & 100 & 72 & 68,5 & 48,5 & 37,8 & 77,1 & 0,000 ** \\
\hline IMT 23 & 293 & 87 & 135 & 82 & 68,5 & 48,5 & 37,8 & 77,1 & $0,000^{* *}$ \\
\hline IMT 24 & 256 & 71 & 172 & 98 & 59,8 & 57,9 & 36,3 & 78,3 & 0,000 ** \\
\hline IMT 25 & 209 & 54 & 219 & 115 & 48,8 & 68,0 & 34,4 & 79,5 & 0,000 ** \\
\hline \multicolumn{10}{|l|}{ Laki-laki } \\
\hline IMT 21 & 137 & 44 & 19 & 32 & 87,8 & 42,1 & 62,7 & 75,7 & $0,000^{* *}$ \\
\hline IMT 22 & 127 & 33 & 29 & 43 & 81,4 & 56,6 & 59,7 & 79,4 & 0,000 ** \\
\hline IMT 23 & 112 & 26 & 52 & 40 & 68,3 & 60,6 & 43,5 & 81,2 & 0,000 ** \\
\hline IMT 24 & 94 & 18 & 62 & 58 & 60,3 & 76,3 & 48,3 & 83,9 & 0,000 ** \\
\hline IMT 25 & 76 & 11 & 80 & 65 & 48,7 & 85,5 & 44,8 & 87,4 & 5,614 \\
\hline
\end{tabular}

Keterangan: $* * \mathrm{p}<0,01 ; * \mathrm{p}<0,05$; IMT = indeks massa tubuh; $\mathrm{Se}=$ sensitivitas; $\mathrm{Sp}=$ spesifisitas; A = batasan IMT tinggi dan kadar HDL-kol rendah/tekanan darah tinggi; B = batasan IMT tinggi dan kadar HDL-kol normal-tinggi/tekanan darah normal-rendah; $\mathrm{C}=$ batasan IMT rendah dan kadar HDL-kol rendah/tekanan darah tinggi; D = batasan IMT rendah dan kadar HDL-kol normal-tinggi/tekanan darah normal-rendah; $\mathrm{PV}(+)=$ predictive value positiv; $\mathrm{PV}(-)$

= predictive value negative 
Nazarina, dkk: Batasan IMT dan LP diabetesi di Indonesia untuk prediksi abnormalitas kadar HDL-kolesterol dan tekanan darah

Tabel 7. Sensitivitas dan spesifisitas LP terhadap kadar profil lipid dan tekanan darah berdasarkan jenis kelamin subjek

\begin{tabular}{|c|c|c|c|c|c|c|c|c|c|}
\hline $\mathbf{L P}(\mathbf{c m})$ & $\begin{array}{c}\text { A } \\
\text { (n) }\end{array}$ & $\begin{array}{c}\text { B } \\
\text { (n) }\end{array}$ & $\begin{array}{c}C \\
\text { (n) }\end{array}$ & $\begin{array}{c}\text { D } \\
\text { (n) }\end{array}$ & $\begin{array}{c}\text { Se } \\
(\%)\end{array}$ & $\begin{array}{c}\text { Sp } \\
(\%)\end{array}$ & $\begin{array}{c}\text { PV (+) } \\
(\%)\end{array}$ & $\begin{array}{c}(\mathrm{PV}-) \\
(\%)\end{array}$ & $\mathbf{p}$ \\
\hline \multicolumn{10}{|c|}{ HDL-kol perempuan } \\
\hline LP 76 & 210 & 73 & 54 & 40 & 79,5 & 35,4 & 42,6 & 74,2 & $0,017^{*}$ \\
\hline LP 77 & 197 & 68 & 67 & 45 & 74,6 & 39,8 & 40,2 & 74,3 & $0,007 *$ \\
\hline LP 78 & 196 & 66 & 68 & 47 & 74,2 & 41,5 & 40,9 & 74,8 & $0,003 * *$ \\
\hline LP 79 & 189 & 65 & 75 & 48 & 71,6 & 42,5 & 39,0 & 74,4 & $0,011^{*}$ \\
\hline LP 80 & 179 & 62 & 85 & 51 & 67,8 & 45,1 & 37,5 & 74,3 & $0,023^{*}$ \\
\hline \multicolumn{10}{|c|}{ Tekanan darah sistolik laki-laki } \\
\hline LP 79 & 124 & 28 & 40 & 38 & 75,6 & 57,6 & 48,7 & 81,6 & $0,000 * *$ \\
\hline LP 80 & 121 & 24 & 43 & 42 & 73,8 & 63,6 & 49,4 & 83,4 & $0,000 * *$ \\
\hline LP 81 & 110 & 20 & 54 & 46 & 67,1 & 69,7 & 46,0 & 84,6 & $0,000 * *$ \\
\hline LP 82 & 106 & 17 & 58 & 49 & 64,6 & 74,2 & 45,8 & 86,2 & $0,000 * *$ \\
\hline LP 83 & 98 & 16 & 66 & 50 & 59,8 & 75,8 & 43,1 & 85,9 & $0,000 * *$ \\
\hline LP 84 & 90 & 15 & 74 & 51 & 54,9 & 77,3 & 40,8 & 85,7 & $0,000 * *$ \\
\hline LP 90 & 60 & 8 & 104 & 58 & 36,6 & 87,9 & 35,8 & 88,2 & $0,000 * *$ \\
\hline \multicolumn{10}{|c|}{ Tekanan darah sistolik perempuan } \\
\hline LP 76 & 201 & 74 & 48 & 42 & 80,7 & 36,2 & 46,7 & 73,0 & $0,000 * *$ \\
\hline LP 77 & 190 & 67 & 59 & 49 & 76,3 & 42,2 & 45,4 & 73,9 & $0,000 * *$ \\
\hline LP 78 & 187 & 67 & 62 & 49 & 75,1 & 42,2 & 44,1 & 73,6 & $0,001 * *$ \\
\hline LP 79 & 183 & 63 & 66 & 53 & 73,5 & 45,7 & 44,5 & 74,4 & $0,000 * *$ \\
\hline LP 80 & 178 & 55 & 71 & 61 & 71,5 & 52,6 & 46,2 & 76,4 & $0,000 * *$ \\
\hline LP 81 & 164 & 52 & 85 & 64 & 65,9 & 55,2 & 42,9 & 75,9 & $0,000 * *$ \\
\hline \multicolumn{10}{|c|}{ Tekanan darah diastolik laki-laki } \\
\hline LP 79 & 117 & 37 & 39 & 39 & 75,0 & 51,3 & 50,0 & 75,9 & $0,000 * *$ \\
\hline LP 80 & 113 & 34 & 43 & 42 & 72,4 & 55,3 & 49,4 & 76,9 & $0,000 * *$ \\
\hline LP 81 & 102 & 29 & 54 & 47 & 65,4 & 61,8 & 46,5 & 77,9 & $0,000 * *$ \\
\hline LP 82 & 99 & 25 & 57 & 51 & 63,5 & 67,1 & 47,2 & 79,8 & $0,000 * *$ \\
\hline LP 83 & 92 & 22 & 64 & 54 & 58,9 & 71,1 & 45,8 & 80,7 & $0,000 * *$ \\
\hline LP 84 & 86 & 19 & 70 & 57 & 55,1 & 75,0 & 44,9 & 81,9 & $0,000 * *$ \\
\hline LP 87 & 69 & 15 & 87 & 61 & 44,2 & 80,3 & 41,2 & 82,1 & $0,000 * *$ \\
\hline LP 88 & 63 & 13 & 93 & 63 & 40,4 & 82,9 & 40,4 & 82,9 & $0,001 * *$ \\
\hline LP 89 & 59 & 13 & 97 & 63 & 37,8 & 82,9 & 39,4 & 81,9 & $0,002 * *$ \\
\hline LP 90 & 55 & 11 & 101 & 65 & 35,3 & 85,5 & 39,2 & 83,3 & $0,002 * *$ \\
\hline
\end{tabular}

Keterangan: $* * \mathrm{p}<0,01 ; * \mathrm{p}<0,05 ; \mathrm{LP}=$ lingkar perut; Se = sensitivitas; $\mathrm{Sp}=$ spesifisitas; A = batasan LP tinggi dan kadar HDL-kol rendah/tekanan darah tinggi; $\mathrm{B}=$ batasan LP tinggi dan kadar HDL-kol normal-tinggi/tekanan darah normal-rendah; $\mathrm{C}=$ batasan LP rendah dan kadar HDL-kol rendah/tekanan darah tinggi; D = batasan LP rendah dan kadar HDL-kol normal-tinggi/ tekanan darah normal-endah; $\mathrm{PV}(+)=$ predictive value positiv; $\mathrm{PV}(-)=$ predictive value negative

$\mathrm{p}=0,00)$ dapat diprediksi menggunakan ukuran LP dengan nilai AUC subjek laki-laki lebih tinggi dibandingkan perempuan (Tabel 5). Namun, untuk memprediksi tekanan darah diastolik tinggi, LP hanya dapat digunakan pada subjek laki-laki (AUC=0,68; $\mathrm{p}=0,000)$. Sebaliknya, untuk memprediksi kadar HDL-kol tinggi, LP hanya dapat digunakan pada subjek perempuan ( $\mathrm{AUC}=0,59 ; \mathrm{p}=0,04)$.

Pada penelitian ini (Tabel 6), prediksi kadar HDLkol rendah dapat menggunakan batasan $\mathrm{IMT}=23 \mathrm{~kg} / \mathrm{m}^{2}$ untuk subjek diabetes laki-laki ( $\mathrm{Se}=63,3 \%$; $\mathrm{Sp}=54,0 \%$; $\mathrm{p}=0,040)$ dan perempuan $(\mathrm{Se}=72,3 \% ; \mathrm{Sp}=47,8 \%$; $\mathrm{p}=0,000)$. Batasan IMT $\left(23 \mathrm{~kg} / \mathrm{m}^{2}\right)$ juga dapat digunakan untuk prediksi tekanan darah sistolik $(\mathrm{Se}=68,3 \%$; $\mathrm{Sp}=60,6 \% ; \mathrm{p}=0,000)$ dan diastolik ( $\mathrm{Se}=68,3 \% ; \mathrm{Sp}=60,6 \%$; $\mathrm{p}=0,000)$ subjek diabetes laki-laki. Sementara itu, Tabel 7 menunjukkan bahwa batasan $\mathrm{LP}=80 \mathrm{~cm}$ dapat untuk memprediksi tekanan darah sistolik tinggi pada subjek perempuan $(\mathrm{Se}=71,5 \% ; 52,6 \% ; \mathrm{p}=0,000)$ dan laki-laki 
$(\mathrm{Se}=73,8 \% ; \mathrm{Sp}=63,6 \% ; \mathrm{p}=0,000)$. Prediksi tekanan darah diastolik tinggi pada subjek laki-laki juga dapat menggunakan batasan $\mathrm{LP}=80 \mathrm{~cm}$ ( $\mathrm{Se}=72,4 \% ; \mathrm{Sp}=55,3 \%$; $\mathrm{p}=0,000$ ). Pada saat LP digunakan untuk memprediksi kadar HDL-kol rendah pada subjek diabetes perempuan, batasan LP yang dapat digunakan lebih rendah yaitu 78 $\mathrm{cm}(\mathrm{Se}=74,2 \% ; \mathrm{Sp}=41,5 \% ; \mathrm{p}=0,003)$.

\section{BAHASAN}

Pada umumnya diabetesi akan mengalami dislipidemia. Suatu penelitian mendapatkan bahwa sekitar 50\% diabetesi mengalami dislipidemia. Keadaan dislipidemia ditandai antara lain dengan kadar trigliserida yang tinggi, HDL-kol yang rendah, apolipoprotein-B (apo-B) yang tinggi, dan densitas partikel LDL yang kecil $(15,16)$. Keadaan dislipidemia juga terjadi pada subjek penelitian ini, baik yang berstatus gizi tidak-gemuk/ tidak-obesitas maupun yang berstatus gizi gemuk/obesitas atau yang tidak obesitas sentral maupun yang obesitas sentral. Pada penelitian ini, subjek diabetes memiliki kadar rerata kolesterol total yang tinggi $(>200 \mathrm{mg} / \mathrm{dl})$, LDL-kol tinggi (>100 mg/dl), dan kadar HDL-kol yang rendah. Namun demikian, pada saat subjek dibedakan berdasarkan jenis kelamin dan status obesitas sentral, maka subjek diabetes laki-laki yang tidak obesitas sentral memiliki rerata kadar HDL-kol yang normal $(42,5 \pm 19,1$ $\mathrm{mg} / \mathrm{dl}$ ) meskipun nilai reratanya lebih rendah dari HDLkol perempuan karena batasan HDL-kol perempuan ( $\geq 50$ $\mathrm{mg} / \mathrm{dl})$ lebih tinggi dibandingkan laki-laki ( $\geq 40 \mathrm{mg} / \mathrm{dl})$. Pada umumnya, perempuan memiliki kadar HDL-kol yang lebih tinggi dibandingkan laki-laki. Hasil beberapa penelitian menunjukkan adanya korelasi yang terbalik antara HDL-kol perempuan dengan laki-laki $(17,18)$. Penelitian di Taiwan juga membuktikan bahwa laki-laki yang tidak memiliki penyakit kronis memiliki rerata kadar HDL-kol lebih rendah $(49,75 \pm 11,16 \mathrm{mg} / \mathrm{dl})$ dibandingkan perempuan $(61,29 \pm 13,34 \mathrm{mg} / \mathrm{dl} ; \mathrm{p}<0,001)(19)$.

Hasil penelitian ini menunjukkan bahwa subjek diabetes mengalami dislipidemia, tetapi jika subjek dibedakan berdasarkan status gizi, maka ada perbedaan signifikan $(\mathrm{p}<0,05)$ antarkelompok status gizi. Perbedaan tersebut hanya terjadi pada kadar HDL-kol, yaitu subjek tidak-gemuk/tidak-obesitas memiliki kadar HDL-kol lebih tinggi dibandingkan yang gemuk/obesitas. Selanjutnya, jika subjek diabetes dibedakan berdasarkan jenis kelamin dan status obesitas sentral, maka perbedaan kadar HDLkol yang signifikan $(\mathrm{p}<0,05)$ hanya terlihat pada subjek perempuan, yaitu yang tidak mengalami obesitas sentral memiliki rerata kadar HDL-kol lebih tinggi dibandingkan yang obesitas sentral. Selain mengalami dislipidemia, subjek diabetes penelitian ini juga memiliki tekanan darah yang tinggi $(>130 / 80 \mathrm{mmHg})$. Bahkan, rerata tekanan darah yang tinggi dapat ditemui pada subjek diabetes yang berstatus gizi tidak-gemuk/tidak-obesitas atau tidak obesitas sentral. Diketahui bahwa hipertensi merupakan komorbiditas yang sering dijumpai pada pasien diabetes (20).

Pada penelitian ini, ukuran IMT maupun LP hanya dapat digunakan untuk memprediksi kadar HDL-kol rendah dan tekanan darah tinggi. Seperti yang dianjurkan oleh World Health Organization (WHO), bahwa penggunaan batasan (cut off point) status gizi (IMT) dapat disesuaikan dengan tujuannya yaitu memprediksi faktor risiko penyakit ataupun keadaan kesehatan lainnya (10). Batasan IMT $=23 \mathrm{~kg} / \mathrm{m}^{2}$ yang dihasilkan penelitian ini, dapat membedakan kadar HDL-kol rendah pada subjek perempuan dan laki-laki dengan nilai sensitivitas sedikit lebih tinggi pada perempuan ( $\mathrm{Se}=72,3 \%$; $\mathrm{Sp}=47,8 \%$; $\mathrm{p}=0,000)$ dibandingkan laki-laki $(\mathrm{Se}=63,3 \% ; \mathrm{Sp}=54,0 \%$; $\mathrm{p}=0,040$ ). Batasan IMT laki-laki sebesar $23 \mathrm{~kg} / \mathrm{m}^{2}$ tersebut, lebih rendah dibanding laki-laki Taiwan $(24,74$ $\mathrm{kg} / \mathrm{m}^{2} ; \mathrm{Se}=68,7 \% ; \mathrm{Sp}=58,1 \%$ ), tetapi untuk batasan IMT perempuan sebesar $23 \mathrm{~kg} / \mathrm{m}^{2}$, sama dengan perempuan Taiwan yaitu $23,10 \mathrm{~kg} / \mathrm{m}^{2}(\mathrm{Se}=74,8 \%$; $\mathrm{Sp}=68,2 \%)$ dalam memprediksi kadar HDL-kol rendah (19). Penelitian di Taiwan tersebut dilakukan pada subjek yang tidak memiliki penyakit kronis. Diketahui bahwa penduduk Asia memiliki variasi batasan IMT antara $22-25 \mathrm{~kg} / \mathrm{m}^{2}$ yang dapat digunakan untuk mencerminkan risiko kesehatan. Kisaran batasan IMT tersebut dihasilkan berdasarkan persentase lemak tubuh penduduk Asia. (10).

Nilai sensitivitas dan spesifisitas dari cut-off point IMT yang dihasilkan untuk memprediksi kadar HDL-kol pada penelitian ini masih cukup rendah. Hal tersebut kemungkinan karena IMT dianggap dapat menggambarkan persentase lemak tubuh, tetapi pada kenyataannya ukuran IMT tidak selalu dapat menggambarkan jaringan adiposa atau jaringan lemak. Oleh karena itu, dimungkinkan 
ukuran IMT tidak berhubungan langsung dengan kadar HDL-kol sehingga nilai IMT kurang sensitif dan spesifik untuk menggambarkan kadar HDL-kol. Hal tersebut juga dapat terlihat dari hasil penelitian antara IMT dengan kadar HDL-kol pada individu sehat menunjukkan korelasi yang kurang erat $(\mathrm{r}=-0,346$ untuk perempuan dan $\mathrm{r}=-0,29$ untuk laki-laki; $\mathrm{p}<0,05)$ (19).

Apabila IMT dapat memprediksi kadar HDL-kol rendah pada subjek diabetes perempuan dan laki-laki, maka LP dapat memprediksi kadar HDL-kol hanya pada perempuan dengan nilai $78 \mathrm{~cm}$. Batasan $\mathrm{LP}=78 \mathrm{~cm}$ tersebut lebih rendah dari nilai batasan LP standar yang digunakan di Indonesia untuk jenis kelamin perempuan yaitu $80 \mathrm{~cm}$. Namun, penelitian di Taiwan menghasilkan batasan LP perempuan yang lebih rendah lagi ( $\mathrm{LP}=75,70$; $\mathrm{Se}=71,6 ; \mathrm{Sp}=67,7)$, tetapi penelitian tersebut dilakukan pada subjek tanpa penyakit kronis (19).

Lingkar perut pada penelitian ini hanya dapat memprediksi HDL-kol perempuan, kemungkinan karena obesitas sentral yang menggambarkan lemak intra-abdominal, proporsinya lebih banyak terjadi pada perempuan dibandingkan laki-laki $(63,9 \%$ vs $29,4 \% ; p=0,000)$. Keadaan tersebut berlawanan dengan pernyataan bahwa pada individu non-diabetes, hormon adinopektin dan HDL-kol lebih tinggi pada perempuan dibandingkan laki-laki dan perempuan memiliki insulin lebih sensitif dan subcutaneous fat lebih besar, tetapi lemak intra-abdominal lebih rendah dibandingkan lakilaki $(\mathrm{p}<0,01)(21)$.

Pada penelitian ini, untuk memprediksi tingginya tekanan darah sistolik ( $\mathrm{Se}=68,3 \% ; \mathrm{Sp}=60,6 \%)$ dan diastolik $\left(\mathrm{Se}=68,3 \%\right.$; Sp 60,6\%), IMT $\left(23 \mathrm{~kg} / \mathrm{cm}^{2}\right)$ hanya dapat digunakan pada subjek laki-laki. Batasan tersebut lebih rendah dibandingkan batasan IMT $\left(25,74 \mathrm{~kg} / \mathrm{m}^{2}\right)$ laki-laki Taiwan yang tidak memiliki penyakit kronis ( $\mathrm{Se}=62,4 \%$; $\mathrm{Sp}=66,7 \%$ ) untuk memprediksi hipertensi (19). Selain itu, hal sebaliknya terjadi pada hasil penelitian yang dilakukan pada non-perokok atau pegawai pabrik, yaitu bahwa IMT lebih dapat memprediksi tekanan darah pada perempuan dibandingkan laki-laki $(22,23)$.

Meskipun IMT dapat digunakan untuk prediksi kelainan kadar HDL-kol dan tekanan darah, tetapi nilai sensitivitas dan spesifisitas yang dihasilkan masih rendah. Hal tersebut kemungkinan karena hampir $30-40 \%$ variasi
IMT dipengaruhi oleh genetik dan 60-70\% dipengaruhi oleh lingkungan (24). Lingkungan yang mempengaruhi terjadinya status gizi gemuk pada subjek penelitian ini terutama adalah gaya hidup kebiasaan mengonsumsi makanan manis setiap hari $(57,4 \%)$ dan mengonsumsi buah dan sayur kurang dari 2 porsi per hari $(79,1 \%)$. Sementara itu, kebiasaan merokok dan aktivitas fisik subjek penelitian ini masih tergolong baik. Subjek yang merokok setiap hari persentasenya masih sedikit (17,2\%), demikian pula yang memiliki aktivitas sedentari lebih dari atau sama dengan 3 jam perhari masih rendah $(2,1 \%)$.

Apabila IMT tidak dapat digunakan untuk memprediksi tekanan darah subjek diabetes perempuan, maka LP $(80 \mathrm{~cm})$ dapat digunakan untuk prediksi tekanan darah sistolik subjek diabetes perempuan $(\mathrm{Se}=71,5 \%$; $\mathrm{Sp}=52,6 \%)$ dan laki-laki $(\mathrm{Se}=73,8 \% ; \mathrm{Sp}=63,5 \%$; $\mathrm{p}=0,000)$. Hasil penelitian ini berbeda dengan hasil penelitian lain, yaitu IMT lebih dapat memprediksi tekanan darah pada perempuan dan LP lebih dapat memprediksi tekanan darah laki-laki. Perbedaan terjadi karena penelitian tersebut dilakukan pada usia muda (22) sedangkan pada penelitian ini kebanyakan subjek berusia lebih dari 45 tahun. Batasan LP perempuan $(80 \mathrm{~cm})$ yang dihasilkan penelitian ini, sama dengan batasan LP perempuan $(80 \mathrm{~cm})$ di Asia, tetapi lebih tinggi dibandingkan LP subjek perempuan Taiwan yang bebas penyakit kronis $(76,40 \mathrm{~cm})$ untuk memprediksi hipertensi $(\mathrm{Se}=80,5 \%$; $\mathrm{Sp}=71,3 \%)$ (19).

Pada subjek diabetes laki-laki, $\mathrm{LP}=80 \mathrm{~cm}$ selain dapat memprediksi tekanan darah sistolik yang rendah juga untuk tekanan darah diastolik rendah $(\mathrm{Se}=72,4 \%$; $\mathrm{Sp}=55,3 \% ; \mathrm{p}=0,000)$. Batasan LP laki-laki $(80 \mathrm{~cm})$ pada penelitian ini, lebih rendah dibandingkan LP laki-laki Taiwan $(87,90 \mathrm{~cm})$ yang bebas penyakit kronis $(\mathrm{Se}=64,0$; $\mathrm{Sp}=67,03$ ) untuk memprediksi hipertensi (19). Apabila dibandingkan dengan batasan LP laki-laki Asia $(90 \mathrm{~cm})$, maka batasan LP yang dihasilkan dari kedua penelitian tersebut lebih rendah. Pada penelitian ini, saat LP berada di posisi $90 \mathrm{~cm}$, sensitivitas LP untuk prediksi tekanan darah sistolik $(\mathrm{Se}=36,6 \%)$ dan diastolik $(\mathrm{Se}=37,8 \%)$ menjadi sangat menurun.

Batasan LP laki-laki $(80 \mathrm{~cm})$ yang rendah pada penelitian ini juga tidak sejalan dengan penelitian lain terkait hormon adinopektin. Dikatakan bahwa hormon adinopektin 
pada laki-laki lebih rendah dibanding perempuan $(\mathrm{p}<0,0001)$ dan hormon adinopektin berkorelasi terbalik dengan lemak intra-abdominal ( $\mathrm{r}=0,3 ; \mathrm{p}<0,0001)$ (21). Dengan demikian ada kecenderungan bahwa laki-laki memiliki lemak intraabdominal lebih besar dibandingkan perempuan, tetapi penelitian tersebut dilakukan pada non-diabetes sehingga kemungkinan keadaan hormon adinopektin pada laki-laki dan perempuan diabetes berbeda dengan non-diabetes. Selain itu, dimungkinkan batasan LP yang rendah pada subjek diabetes laki-laki untuk memprediksi tekanan darah tinggi disebabkan penelitian ini tidak mempertimbangkan penggunaan obat hipertensi dan kepatuhan penggunaan obat anti-hipertensi oleh subjek.

\section{SIMPULAN DAN SARAN}

Pada subjek diabetes laki-laki dan perempuan, di antara kadar profil lipid dan tekanan darah, yang dapat diprediksi kelainannya dengan IMT dan LP adalah kadar HDL-kol dan tekanan darah sistolik. Fungsi IMT dan LP dalam memprediksi masing-masing berbeda. Kadar HDLkol rendah pada laki-laki dan perempuan dapat diprediksi menggunakan IMT $=23 \mathrm{~kg} / \mathrm{cm}^{2}$ sedangkan untuk prediksi tekanan darah sistolik tinggi pada perempuan dan lakilaki dapat digunakan $\mathrm{LP}=80 \mathrm{~cm}$.

Perlu dipertimbangkan bahwa batasan IMT dan LP yang dihasilkan dari penelitian ini umumnya memiliki sensitivitas dan spesifisitas yang masih rendah yaitu di bawah $70 \%$. Hal tesebut dapat disebabkan adanya keterbatasan dalam penelitian ini yaitu tidak mempertimbangkan penggunaan obat anti-hipertensi, obat diabetes atau suplemen yang bisa mempengaruhi kadar profil lipid dan tekanan darah, etnik, usia, durasi diabetes, dan gaya hidup lainnya. Oleh karena itu, masih diperlukan penelitian lebih lanjut untuk melihat konsistensi hasil penelitian ini. Selain itu, diperlukan juga penelitian serupa pada subjek non-diabetes sehingga hasilnya dapat diperbandingkan dengan subjek diabetes.

\section{UCAPAN TERIMAKASIH}

Kami mengucapkan terimakasih kepada Badan Litbangkes, Kementerian Kesehatan yang telah mendanai penelitian ini sebagai bagian dari analisis lanjut data Riskesdas 2007.

\section{RUJUKAN}

1. Kariadi SHKS. Kecenderungan global dalam pengendalian diabetes. Progress in Diabetology and Related Disorders: from Bench to Clinical Pratice; Forum Diabetes Nasional III. Bandung: PERKENI; 2005.

2. Kemenkes RI. Riset kesehatan dasar (Riskesdas) 2013. Jakarta: Kemenkes RI; 2013.

3. Dagogo. Neuroendocrine regulation of food intake. Nutrition and diabetes; pathophysiology and management. Opara E, editor. Boca Raton: CRC Press, Taylor and Francis Group; 2005.

4. Hossain P, Kawar B, Nahas MEI. Obesity and diabetes in developing world - a growing challenge. N Engl J Med 2007;356:213-5.

5. Leibson CL, Williamson DF, Melton III LJ, Palumbo PJ, Smith SA, Ransom JE, Schilling PL, Narayan KMV. Temporal trends in BMI among adults with diabetes. Diabetes Care 2001;24(9):1584-9.

6. Adi S. The importance of tight blood glucose control in cardiovascular complications. Progress in Diabetology and Related Disorders: from Bench to Clinical Pratice; Forum Diabetes Nasional III. Bandung: PERKENI; 2005.

7. Wang Y, Rimm EB, Stampfer MJ, Willet WC, Hu FB. Comparison of abdominal adiposity and overall obesity in predicting risk of type 2 diabetes among men. Am J Clin Nutr 2005;81(3):555-63.

8. Snijder MB, van Dam RM, Visser M, Seidell JC. What aspects of body fat are particularly hazardous and how do we measure them? Int J Epidemiol 2006;35:83-92.

9. Klein LC, Corwin EJ, Ceballos RM. Leptin, hunger, and body weight: influence gender, tobacco, smoking, and smoking abstinence. Addictive Behaviour 2004;29(5):921-7.

10. WHO expert consultation. Appropiate body-mass index for Asian populations and its implications for policy and intervention strategies. Lancet 2004;363:157-63.

11. Guricci S, Hartriyani Y, Hautvast JG, Deurenberg P. Prediction extracellular water and total body water by multifrequency bio-electrical impedance in Southeast Asian population. Asia Pac J Clin Nutr 1999;8(2):155-9.

12. Almatsier S, Instalasi Gizi RSCM. Penuntun diet. Jakarta: Gramedia; 2003.

13. PERKENI. Konsensus pengelolaan dan pencegahan diabetes mellitus tipe 2 di Indonesia. Jakarta: PERKENI; 2011.

14. Zou KH, Liu A, Bandos AI, Ohno-Machado L, Rockette HE. Statistical evaluation of diagnostic performance topicx in ROC analysis. Boca Raton: CRC Press; 2012.

15. Shah SZA, Devrajani BR, Devrajani T, Bibi I. Frequency of dyslipidemia in obese versus non-obese in relation to body mass index (BMI), waist hip ratio (WHR) and waist circumference (WC). Pakistan Journal of Science 2010;62(1). 
16. Kayode JA, Sola AO, Matthew AS, Adesola BO, Ademola I, Adedeji AT, Adelani AS. Lipid profile of type 2 diabetic patients at rural tertiary hospital in Nigeria. J Diabetes Endicronol 2010;1(4):46-51.

17. Pietrobelli A, Lee RC, Capristo E, Deckelbaum RJ, Heymsfield SB. An independent, inverse association of highdensity-lipoprotein cholesterol concentration with nonadipose body mass. Am J Clin Nutr 1999;69(4):614-20.

18. Schroder H, Marrugat J, Elosua R, Covas MI. Relationship between body mass index, serum cholesterol, leisure-time physical activity, and diet in a Mediterranean Southern-Europe population. British Journal Nurtrition 2003;90:431-9.

19. Li WC, Chen IC, Chang YC, Loke SS, Wang SH, Hsiao KY. Waist-to height ratio, waist circumference, and body mass index as indices of cardiometabolic risk among 36,642 Taiwanese adults. Eur J Nutr 2013;52(1):57-65.

20. Mancia $\mathrm{G}$. The association of hypertension and diabetes: prevalence, cardiovascular risk and protection by blood pressure reduction. Acta Diabetol 2005;42:S17-S25.
21. Baratta R, Amato S, Degano C, Farina MG, Patanè G, Vigneri R, Frittitta L. Adinopectin relationship with lipid metabolism is independent of body fat mass: evidence from both cross-sectional and intervention studies. J Clin Endocrinol Metab 2004;89(6):2665-71.

22. Benetou V, Bamia C, Trichopoulos D, Mountokalakis T, Psaltopoulou T, Trichopoulou A. The association of body mass index and waist circumference with blood pressure depends on age and gender: a study of 10,928 nonsmoking adults in the Greek EPIC cohort. Eur J Epidemiol 2004;19(8):803-9.

23. Sakurai M, Miura K, Takamura T, Ota T, Ishizaki M, Morikawa Y, Kido T, Naruse Y, Nakagawa H. Gender difference in the association between anthropometric indices of obesity and blood pressure in Japanese. Hypertens Res 2006;29(2):75-80.

24. Pi-Sunyer FX. The obesity epidemic: pathophysiology and consequences of obesity. Obes Res 2002;10(2):97S$104 \mathrm{~S}$. 